УДК 378.016:811.111

DOI: $10.15330 /$ esu. $15.145-152$
Ярослав Черньонков,

кандидат педагогічних наук, доцент,

Центральноукраїнський державний педагогічний університет імені В. Винниченка

(м. Кропивницький, Україна)

Yaroslav Chernionkov,

Candidate of pedagogical sciences $(\mathrm{PhD})$,

Associate Professor, Volodymyr Vynnychenko

Central Ukrainian State Pedagogical University

(Kropyvnytskyi Ukraine)

yarcher78professor@gmail.com

\title{
ПРОФЕСІЙНА МОБІЛЬНІСТЬ МАЙБУТНЬОГО ВЧИТЕЛЯ ІНОЗЕМНИХ МОВ: ПСИХОЛОГІЧНІ ТА ПЕДАГОГІЧНІ УМОВИ
}

\section{PROFESSIONAL MOBILITY OF THE FUTURE TEACHER OF FOREIGN LANGUAGES: PSYCHOLOGICAL AND PEDAGOGICAL CONDITIONS}

Дане досліджения було проведено з метою визначения основних характеристик теоретико-методологічних основ понять "мобільність", "професійна мобільність майбутнього вчителя іноземних мов", "умов", "педагогічних умов" у вицих навчальних закладах. Автор дослідив, проаналізував і окреслив провідні психолого-педагогічні умови професійної мобільності майбутніх фахівиів у сфері іноземних мов (активність практично-педагогічной діяльності іноземною мовою; адаптивність студентів в різиих умовах, колективах, ситуачіях, професіях; психологічна підтримка прочесу формування професійної мобільності через індивідуальну траєкторію професійної підготовки та професійної реалізачіi). Автор проаналізував і визначив "педагогічні умови" як: набір необхідних факторів, критеріїв, характеристик, методів; організованого середовица, ио впливає на якісне та ефективне вдосконалення прочесу формування професійної мобільності майбутніх учителів іноземної мови у вицих навчальних закладах.

Визначено основні чинники та критерій прочесу формування професійної мобільності студентів іноземних мов (адміністративно-організачійного, змістового, методологічного та особистісного рівнів). На адміністративно-організаційному рівні такі фактори включають: створення кредитної-модульної системи; прийняття єдиної європейськой рамки кваліфікачій; існування системи взаємного визнання кваліфікачій та дипломів; створения системи взасмного визнания періодів навчания в іниих свропейських вищих навчальних закладах. На змістовому рівні провідними факторами у забезпеченні професійної та педагогічної мобільності майбутніх учителів с: інтериаціоналізачія змісту навчання та активізачія впровадження мови міжнародного спілкування. На методологічному рівні фактори пов'язані з передачею основного акценту на розвиток критичного мислення, творчості, здатності виріиувати проблеми, очінки ризиків, прийняття рімень, конструктивного вираження почуттів, активізацій проектнодослідної діяльності, рефлексивного мисления. На індивідуальному рівні були визначені фактори, які зосереджують увагу на внутріиній мотиваиї̈ особистості та здатності виріиувати проблеми, пов'язані з культурними інтересами, прагнениями уникиути повсякденного життя.

Ключові слова: мобільність, професійна мобільність, професійна мобільність майбутнього вчителя іноземних мов, вищих навчальних закладів (ВН3), психологопедагогічні умови, фактори та критерії формування мобільності.

This research has been conducted to determine the main characteristics of the theoretical-methodological basis of the concepts of "mobility", "professional mobility of the future teacher of foreign languages", "conditions", "pedagogical conditions" at institutions of higher education. The author has researched, analyzed and outlined the leading psychological- 
pedagogical conditions of future specialists' professional mobility in the field of foreign languages (activity of practical-pedagogical action in a foreign language, students' adaptability in different conditions, collectives, situations, professions, psychological support for the process of professional mobility' s formation through an individual trajectory of professional training and professional implementation). The author analyzed and defined "pedagogical conditions" as: a set of necessary factors, criteria, characteristics, methods; the so-called organized environment that influences the qualitative and effective improvement of the process of forming the professional mobility of future foreign language teachers in higher education institutions.

The main factors and criteria of the process of formation of foreign languages students' professional mobility (administrative-organizational, content, methodological and personal levels) have been determined. At the administrative-organizational level, such factors include: the establishment of a credit system; adoption of a common European qualifications framework; the existence of a system of mutual recognition of qualifications and diplomas; the establishment of a system of mutual recognition of periods of study in another European higher educational institutions. At the content level, the leading factors in ensuring the professional and pedagogical mobility of future teachers are: the internationalization of the content of learning and the activation of the introduction of lingua franca (language of international communication). At the methodological level, factors associated with the transfer of the main emphasis on the development of critical thinking, creativity, ability to solve problems, risk assessment, decision-making, constructive expression of feelings, activation of design and research activity, reflective thinking. At the individual level, factors have been identified that focus on internal motivation of the individual and the ability to solve problems related to cultural interests, aspirations to avoid daily routine.

Key words: mobility, professional mobility, professional mobility of the future teacher of foreign languages, higher education institutions (HEI), psychological-pedagogical conditions, factors and criteria of the formation of mobility.

Defining of the problem and the analysis of the last researches and publications. Improving socio-communicative relations, globalization and educationalintegration processes of Europeanization reformed the linguistic content of the once monolingual states and the continent as a whole. New conditions contributed to the formation of a permanent need for knowledge of foreign languages in most European residents, which has increased the focus on foreign language studying at all levels of the education system: both within organized and non-organized studying. In such conditions, organizational and methodological principles of training specialists for work in different target groups should be reviewed in the context of psychological-pedagogical conditions for the formation of the mobility of future teachers of foreign languages at higher educational institutions (HEI).

It has been established that the relevance of professional mobility is determined by the dynamism of modern social transformations, which demands the specialists who are able to adopt and implement non-standard solutions in situations of educational competition. As the analysis showed, an "important" role in the study of professionalpedagogical mobility is played by the "ideal", which should be sought in the professional training of teachers. In the scientific literature, the concept of "professionally mobile teacher" has become widespread, which means a person who is able to improve, flexibly respond to new demands and conditions of existence, adapt to them (L. Amirova); a person who has a sensitivity to innovative changes in education, the ability to internalize their own resources in order to adapt in an ever-changing educational environment, build up their own resources for solving new problems, and also change the environment, mastering new pedagogical technologies (L. Goryunova); the integrative property of the 
individuality, which involves the dynamic state of the individual, able to flexibly adapt to changing the content and conditions of professional-pedagogical activities, to realize the need for continuous self-education and able to support its professional creative-social potential (I. Nikulina) [6, p. 9-16].

Professional mobility of specialists of different profile became the subject of A. Vashchenko's research (formation of professional mobility of future officers in the process of studying at higher military educational institutions), L. Goryunova (professional mobility of a specialist as a problem of developing Russian education), Ye. Ivanchenko (formation of future economists' professional mobility in the process of studying at higher educational institutions), N. Kozhemyakina (socio-pedagogical conditions for the formation of professional mobility of future managers-agrarians), S. Kugel (professional mobility in science), L. Mitina (professional mobility of the individuality in new socio-cultural conditions), O. Symonchuk (interprofessional mobility and change of social identity), I. Shpektorenko (managerial aspect of staff mobility).

It was found that the main focus of foreign scientists of the so-called "PreBologna" period was on identifying the advantages and disadvantages of the "free movement of knowledge and information" in Europe, the formation of a European policy of an open society of knowledge and an open educational environment in the works on the problem of professional-pedagogical mobility ( D. Brown, L. Sanders, D. Lorillard, R. McBride, C. Watson, S. Modgil, C. Modgil).

"Post-Bologna" researches have been focused on substantiation the organizationalpedagogical conditions aimed at activating the process of mobility formation in the European space of higher education (M. Byram, P. Blumenthal, P. Green, A. Green, K. Gürüz, W. Demmelhuber, etc.).

The analysis of the state of development of the problem of future teachers' professional mobility made it possible to distinguish the following directions of this problem in the scientific researches of domestic and foreign scientists: the philosophical interpretation of the concept of "mobility", "social mobility" (P. Sorokin, M. Tomin, J. Goldtorp, S. Llevelin , S. Payne, R. Machgir, F. Turner, etc.); the problem of professional-pedagogical (D. Brown, L. Sanders, D. Lorillard, R. McBride, C. Watson, C. Modgill, S. Modig, et al.) and academic mobility (P. Blumental, K. Guryuz, V. Demmelguber, F. Derwin) in the writings of European scholars; features of professional mobility of teachers (L. Amirova, O. Amosova, N. Ashcheulova, Z. Bagishayev, S. Zheltova, L. Znovenko, Yu. Kalynovsky, S. Kugel, L. Lyesokhina, , A. Trochin, F. Vanishcott, P. Zgaga). However, the analysis of scientific literature shows that the problem of the development of professional mobility of teachers as an integral part of their preparation did not become the subject of systematic study and special researches.

Identification of previously unsettled parts of the general problem. The feasibility of the study is determined by the theoretical and practical significance of the tasks of forming the professional mobility of future skilled teachers of foreign languages and a number of actual contradictions between them:

- the need for introduction of innovative, professionally oriented pedagogical technologies and insufficient psychological-pedagogical and methodical training of a part of teachers;

- the need for purposeful formation of professional mobility and the lack of appropriate scientific and methodological support. 
Therefore, the main task of this study is the disclosure of the essence of previously unresolved issues on the problem, namely:

- To analyze the main pedagogical approaches to the definition of the essence of the concept of "professional mobility", "professional mobility of the future teacher of foreign languages", "conditions" in the scientific literature;

- To identify and highlight the factors and criteria that contribute to the process of professional mobility;

- To outline the possibilities of using the experience of EU countries in the formation of future teachers' professional mobility at the higher educational institutions of Ukraine.

The purpose of writing the article is to carry out the psychological-pedagogical conditions of forming the mobility of future teacher of foreign languages.

The main material. Socio-political changes have led to significant changes in the language sphere, which in turn leads to a revision of the professional training of foreign language teachers in view of the requirements of multilingual education. In the context of multilingual education, the multilingual and cross-cultural competence of the teacher is of particular importance, including not only knowledge of several foreign languages, acquaintance with different cultures and tolerant attitude to them, but also the emerging European identity. It is also important during the training at the pedagogical university to involve students in the preparation of curricula for different target groups, to develop skills in the remote mode, using the possibilities of ICT. Also, motivate future specialists in the field of foreign languages into activity-adaptability-mobility.

The term "mobility" in the general explanation has the following interpretation: mobile (from Lat. Mobilis - mobile) - this is mobility, the ability to move quickly, action. In the structure of professional mobility there is a separate important element of it - professional training, which is in fact the academic mobility of the individuality, which largely determines the formation of professional mobility. Professional mobility has been characterized as the ability of a person to self-organize quickly and efficiently, to change according to life and professional needs, to adapt to a certain professional environment and professional groups and, ultimately, to work effectively [4, pp. 25-32].

Consequently, taking into account all of the above, we can determine the professional mobility of the future teacher of foreign languages in the process of individualization of professional training at HEI as: complex system education, integral quality of the future specialist of foreign languages and the activity of the educator that is formed and manifested in the process of professional training, retraining, self-education and specialist's creative self-realization, that is, understood as a possible strategy for the professionalization of teaching staff; the quality of the personality that is essential for the successful life and studying of the student in a modern society, which manifests itself in work and ensures self-determination, self-realization in life and profession through the formation of key qualifications and the desire of future teachers of foreign languages to change not only themselves but also the professional field and training environment; the readiness of a skilled specialist to change professional tasks, to change the workplace, the ability to master new types of work quickly, new specialties; as a systemic phenomenon that reflects its ability to become mobile professionally due to the close interaction of the objective (environment, personnel policy, etc.) and subjective aspects (personal qualities), the degree of their effectiveness, achievement; a complex concept that includes a set of system of creating competencies (professional, sociocultural, foreign language, communicative, educational, methodical, professionally oriented, 
intercultural) and has a chain of professional-defining characteristics (self-actualization, self-activation, self-identification, self-improvement, self-development).

The concept of "pedagogical conditions" has been studied in the works of such scholars as L. Voronova, T. Gordeyeva, T. Gutsan, V. Manko, O. Fedorova. In particular, O. Fedorova defines pedagogical conditions as a set of objective possibilities of the content of teaching, methods, organizational forms and material possibilities of their implementation, which ensures the successful solution of the task. At the same time, V. Manko understands "pedagogical conditions" as the interconnected set of internal parameters and external characteristics of the educational process. In her research, T. Gutsan notes that the pedagogical conditions must reflect the shape of the readiness of future specialists to work in the context of specialized education $[8$, p. 200] and professional training of specialists at the HEI.

We consider "pedagogical conditions" as the so-called organized environment ( $a$ set of necessary factors, criteria, characteristics, methods) that influences the qualitative and effective improvement of the process of forming the professional mobility of future foreign language teachers at the HEI.

In the context of our research, the problem of individualization of the future teacher's professional training, the conceptual aspects of the research of this issue by different scholars should be highlighted. So L. Voronova circles the following pedagogical conditions: a) actualization of the modern model of the profession in the educational process of higher education (finding information about the options for the development of the profession, motivation to self-awareness of possible ways of selfrealization); b) activation of communication links in the process of professional training (assistance in attracting personal contacts of students); c) facilitating the student's choice of the trajectory of professional training and professional implementation (assistance in training according to an individual schedule) [8, p. 200].

The researcher T. Gordeyeva. substantiated the following pedagogical conditions: the formation of motivation for professional mobility and its self-development; enriching the content of professional disciplines with the topics related to the formation of professional mobility; the usage of methods and forms of professional mobility in the process of practical activity [3, pp. 26-29].

The analysis of this concept of a scientist N. Zhitnyk deserves our attention, which outlines the following pedagogical conditions: - scientific and methodological implementation of the process of training future teachers of foreign languages; introduction of advanced technologies into the training process; - organization of independent work of students; - activation of research activity of both teachers and students; - realization of differentiation of the training process in order to ensure a person-oriented approach [5]. We also have to add individualization of the professional training of the future teacher of foreign languages.

Since the subject of our study is the mobility of the future teacher of foreign languages, it is logical to analyze the psychological-pedagogical conditions for the formation of this concept. In particular, the scientist K. Vyshnevska distinguishes the following psychological-pedagogical conditions of mobility of students of foreign languages: the presence of communicative-professional orientation in the introduction of foreign languages; the usage of interdisciplinary connections; involvement of students in imitative-role-based practical activity [1, pp. 10-18].

The effectiveness of pedagogical conditions of forming the readiness of the future teacher of foreign languages for innovation activity has been checked by the researcher 
O. Goncharova: formation of the future teacher of a foreign language as a subject of educational innovations in the process of mastering a foreign language (creating opportunities for self-determination of students regarding the subject, content, goals and methods of innovation, availability freedom of choice in the design of author's projects); readiness of the student to overcome the difficulties and stereotypes that accompany the adoption of new in pedagogical practice; the presence of a future teacher of a set of resources for innovation (development of innovation potential, stimulation of innovation activity, application of innovative technologies in the process of conducting pedagogical practices in school); timely diagnosis of the readiness level of the future teacher of a foreign language for innovation activity [2, p. 17].

In the process of developing our research, the factors and criteria of professional mobility formation of the future language specialists require a more detailed analysis. Therefore, we agree with the scientist Y. Klymenko's, who identified the factors of forming the mobility of higher educational institutions' students, which covers the administrative-organizational, content, methodological and personal levels.

At the administrative-organizational level, such factors are included: the establishment of a credit system; adoption of a common European qualifications framework; the existence of a system of mutual recognition of qualifications and diplomas; the establishment of a system of mutual recognition of study periods in another European higher educational institution; action programs such as SOCRATES / ERASMUS (European Mobility and Co-operation Educational Programs); individualization of study and academic freedom of students; standardization of educational activity, autonomy of higher institutions of pedagogical education; the flexibility of education; distance learning forms; introduction of favorable visa policy, friendly service services [6, p. 14-16].

At the content level, the leading factors in ensuring the professional-pedagogical mobility of future teachers are: the internationalization of the content of learning and the activation of the introduction of lingua franca (language of international communication); implementation of the concept of multilingual education; the introduction of a competent approach when drawing up internationalized curricula [7, p. 74-75].

At the methodological level, main factors are connected with the transfer of the main emphasis on the development of critical thinking, creativity, ability to solve problems, risk assessment, decision-making, constructive expression of feelings, activation of design and research activity, reflective thinking [7, p. 76-77].

At the individual level, basic factors that focus on internal motivation of the individuality and the ability to solve problems related to cultural interests, aspirations to avoid daily routine have been identified. An important condition for the development of professional mobility is the pedagogical counseling on professional-pedagogical mobility issues - preparing students for mobility programs (informational, psychological, legal), including holding set-up sessions and organization of meetings with graduates of mobility programs $[7, \mathrm{p} .77]$.

In the process of forming the professional mobility of the future teacher of foreign languages at higher educational institutions we distinguish the following psychologicalpedagogical conditions:

- Formation of motivation for professional mobility and its self-development; enriching the content of professional disciplines with the topics related to the formation of professional mobility; the use of methods, forms of professional mobility development in the process of practical activity; 
- The presence of a communicative-professional orientation in the introduction of foreign languages; use of interdisciplinary connections; engaging students in simulation and role-based practical activities;

- Focusing on the process of professional training on the development of the speed and flexibility of thinking in a foreign language; introduction of interactive methods of training future teachers of foreign languages; the use of non-traditional methods of organizing professional training at the faculties of foreign languages;

- Activity of practical-pedagogical action in a foreign language; adaptability of students in different conditions, collectives, situations, professions;

- Psychological support of the process of formation of professional mobility through an individual trajectory of professional training and professional implementation.

Conclusions and recommendations for further research. We understand that our observation is only part of the research program we have created for this issue. Further studies we see in working out the general methodological characteristics of the professional mobility in the process of individualization of students' training at higher educational institutions.

1. Вишневська К.Г. Педагогічні умови професійно-оріснтованого навчання іноземних мов майбутніх фахівців економічного профілю: автореф. дис....канд. пед.наук / К.Г. Вишневська. - Одеса, 2011. - $21 \mathrm{c}$.

2. Гончарова О.А. Педагогічні умови підготовки майбутнього вчителя іноземних мов до інновацій ної діяльності: автореф. дис. ... канд.. пед. наук 13.00.04. - Теорія та методика професійної підготовки / О.А. Гончарова. - К, 2008. - 22 с.

3. Гордеева Т.Е. Обоснование педагогических условий формирования профессиональной мобильности будущих социальных работников / Т.Е. Гордеева // Science and Education a New Dimension. Pedagogy and Psychology. - Volume II (11), Issue: 22. - Budapest, 2014 - C. 26-29.

4. Грицькова Н. В. Професійна мобільність фахівця: сутність та структура / Грицькова Н.В // Вісник ЛНУ ім. Т. Шевченка. 2010. №12 (199). С. 25-32.

5. Житник Н.В. Організаційно-педагогічні умови підготовки бакалаврів економіки в коледжі II рівня акредитації: дис... канд. пед. наук. / Житник Н.В. - Кривий Ріг, 2001. - 223 с.

6. Клименко Ю.А. Професійна мобільність майбутніх учителів у країнах Євросоюзу: автореф. дис. ... канд. пед. наук : 13.00.04 / Ю. А. Клименко; Уман. держ. пед. ун-т ім. П. Тичини. Умань, 2011. - 20 c.

7. Клименко Ю. А. Педагогічні умови формування професійно мобільного педагога у європейських вищих навчальних закладах / Ю. А. Клименко // Педагогічні науки : зб. наук. праць.- Херсон: Видавництво ХДУ, 2011. - Вип. 58. - С. 74-79.

8. Чорна I.I. Обгрунтування педагогічних умов формування мобільності майбутніх економістів засобами іноземної мови у процесі навчання у вищому навчальному закладі / I. I. Чорна // Збірник наукових праць [Херсонського державного університету]. Педагогічні науки. 2017. - Вип. 79(1). - С. 199-203.

\section{References}

1. Vyshnevska K.H. Pedahohichni umovy profesiino-oriientovanoho navchannia inozemnykh mov maibutnikh fakhivtsiv ekonomichnoho profiliu: avtoref. dys....kand. ped.nauk / K.H. Vyshnevska. Odesa, 2011. - 21 s. [ukr].

2. Honcharova O.A. Pedahohichni umovy pidhotovky maibutnoho vchytelia inozemnykh mov do innovatsii noi diialnosti: avtoref. dys. ... kand.. ped. nauk 13.00.04. - Teoriia ta metodyka profesiinoi pidhotovky / O.A. Honcharova. - K, 2008. - 22 s. [ukr].

3. Hordeeva T.E. Obosnovanye pedahohycheskykh uslovyi formyrovanyia professyonalnoi mobylnosty budushchykh sotsyalnyikh rabotnykov / T.E. Hordeeva / Science and Education a New Dimension. Pedagogy and Psychology. - Volume II (11), Issue: 22. - Budapest, 2014. - C. 26-29. [rus].

4. Hrytskova N. V. Profesiina mobilnist fakhivtsia: sutnist ta struktura / Hrytskova N.V // Visnyk LNU im. T. Shevchenka. 2010. №12 (199). S. 25-32. [ukr]. 
5. Zhytnyk N.V. Orhanizatsiino-pedahohichni umovy pidhotovky bakalavriv ekonomiky v koledzhi II rivnia akredytatsii: dys... kand. ped. nauk. / Zhytnyk N.V. - Kryvyi Rih, 2001. - 223 s. [ukr].

6. Klymenko Yu.A. Profesiina mobilnist maibutnikh uchyteliv u krainakh Yevrosoiuzu: avtoref. dys. ... kand. ped. nauk : 13.00.04 / Yu. A. Klymenko; Uman. derzh. ped. un-t im. P. Tychyny. — Uman, 2011. - 20 s. [ukr].

7. Klymenko Yu. A. Pedahohichni umovy formuvannia profesiino mobilnoho pedahoha u yevropeiskykh vyshchykh navchalnykh zakladakh / Yu. A. Klymenko // Pedahohichni nauky : zb. nauk. prats.- Kherson: Vydavnytstvo KhDU, 2011. - Vyp. 58. - S. 74-79. [ukr].

8. Chorna I.I. Obhruntuvannia pedahohichnykh umov formuvannia mobilnosti maibutnikh ekonomistiv zasobamy inozemnoi movy u protsesi navchannia u vyshchomu navchalnomu zakladi / I. I. Chorna // Zbirnyk naukovykh prats [Khersonskoho derzhavnoho universytetu]. Pedahohichni nauky. - 2017. - Vyp. 79(1). - S. 199-203. [ukr].

Одержано статтю: 5.02.2019

Прийнято до друку: 19.03.2019

УДК $376-056.36(73)$

DOI: $10.15330 /$ esu. $15.152-160$

\section{Світлана Чупахіна,}

кандидат педагогічних наук, доцент, ДВНЗ “Прикарпатський національний університет імені Василя Стефаника" (м. Івано-Франківськ, Україна)

Svitlana Chupakhina,

Candidate of pedagogical sciences $(\mathrm{PhD})$, Associate Professor, Vasyl Stefanyk Precarpathian national university (Ivano-Frankivsk, Ukraine)

cvitlana2706@gmail.com

\section{ВИКОРИСТАННЯ ІНФОРМАЦЙНИХ ТЕХНОЛОГІЙ В НАВЧАННІ ДІТЕЙ 3 ОСОБЛИВИМИ ОСВІТНІМИ ПОТРЕБАМИ: ДОСВІД США}

\section{USAGE OF INFORMATIONAL TECHNOLOGIES IN TEACHING OF CHILDREN WITH SPECIAL EDUCATIONAL NEEDS: EXPERIENCE OF THE USA}

В статті проаналізовано досвід американських учителів щодо використання інформачійних технологій у роботі з дітьми з особливими освітніми потребами в умовах інклюзивного навчання. Важливо зауважсити, щзо запровадження в Украйні інклюзивного навчання та зміна системи освіти загалом співпали у часі з інтенсивним розвитком цифрових комунікачій. Відтак важливим завданиям сучасної иколи стас повнота використання можливостей інформаційних технологій, їх потенціалу в навчанні дітей з особливими освітніми потребами. Актуальності набуває саме вивчення та розумне застосувания досвіду американських педагогів, співзвучного загальносвітовим тенденціям оновлених підходів до освіти в Украйні.

Проаналізовано теоретико-методологічні основи, стан та тендениій використання інформачійних технологій в освіті учнів з особливими освітніми потребами в США задля успішного їх використання в умовах інклюзивного освітнього середовича України.

Доведено, ио використания потенчіалу інформачійних технологій, як засобу навчання, так $і$ способу оволодіння ними на належному рівні, стає найважливіших завдань підготовки сучасних фахівиів в галузі освіти.

Аргументовано, ио освітній прочес слід організовувати таким чином, иоб кожна дитина, чи з проблемами фізичного/психічного здоров'я чи з “типовим” розвитком, мала можливість самостійно виконувати завдання у зручному для ней темпі та могла демонструвати власні досягнення.

Узагальнено, що проблеми, які обмежують використання інформачійних технологій в освіті дітей з особливими освітніми потребами в США, здебільиого універсальні, тобто с спільними на иляху інформатизачії освіти в краӥні загалом, водночас вони схожі з перешкодами, які гальмують інформатизачію вітчизняної освіти. 